\title{
Changes in antioxidant status of heart muscle tissue in experimental diabetes in rabbits
}

\author{
Anna Gumieniczek ${ }^{1 \bowtie}$, Hanna Hopkała ${ }^{1}$ Zbigniew Wójtowicz $^{2}$ and Justyna Nikołajuk ${ }^{1}$ \\ ${ }^{1}$ Department of Medicinal Chemistry, and ${ }^{2}$ Department of Human Physiological Anatomy, \\ Medical University of Lublin, Lublin, Poland
}

Received: 11 October, 2001; revised: 20 March, 2002; accepted: 09 May, 2002

Key words: alloxan-induced diabetes, heart muscle tissue, oxidative stress, antioxidant status, lipid peroxidation

\begin{abstract}
The present study was designed to evaluate the oxidative stress-related parameters in alloxan-induced diabetes in rabbits. After 3, 6, 12 and 24 weeks of hyperglycaemia the enzymatic and non-enzymatic factors were measured in heart tissue of diabetic and control groups. Superoxide dismutase and glutathione peroxidase activities and the contents of total sulfhydryl compounds significantly increased at all time intervals. Catalase activity increased initially (after 3 and 6 weeks), decreased after 12 weeks and increased again at the 24 th week of the experiment. Glutathione reductase activity increased initially (at 3rd week), decreased below control level after 6 and 12 weeks, then increased again. Ascorbic acid concentration decreased after 3 and 6 weeks, and increased at the 12 th and 24 th weeks. The level of lipid peroxidation products was reduced after 3,6 and 12 weeks of the experiment. After 24 weeks it was significantly elevated.

These data suggest that hyperglycaemia induces oxidative stress in the heart but the defense mechanisms in the heart tissue are fairly efficacious against oxidative injury.
\end{abstract}

It has been shown that elevated extra- and intracellular glucose concentrations result in oxidative stress, which is defined as an imbalance between prooxidants and antioxidants. Several mechanisms seem to be involved in the genesis of this oxidative stress, which has been reported both in experimental diabetes in animals and in diabetic patients: glucose autooxidation, protein glycation and formation of advanced glycation endproducts, and

\footnotetext{
${ }^{凶}$ Corresponding author: Anna Gumieniczek, Medical University of Lublin, Department of Medicinal Chemistry, W. Chodźki 6, 20-093 Lublin, Poland; tel.: (48 81) 740 5871; fax: (48 81) 742 5165; e-mail: kzchl@asklepios.am.lublin.pl
}

Abbreviations: BHT, butylated hydroxytoluene; CAT, catalase; GSH-Px, glutathione peroxidase; GSSG-R, glutathione reductase; 4-HNE, 4-hydroxyalkenals; LPO, lipid peroxidation; MDA, malondialdehyde; S.E.M., standard error of the mean; SOD, superoxide dismutase; TBA, thiobarbituric acid. 
the polyol pathway (West, 2000). On the other hand, oxidative stress is involved in the origin of type 1 diabetes, especially via apoptosis of pancreatic B-cells, as well as insulin resistance in type 2 diabetes (Bonnefont-Rousselot et al., 2000). There is also evidence that elevation in glucose concentration may depress natural antioxidant defense agents such as vitamin C or glutathione (Inouye et al., 1999). Recent experimental findings suggest that overproduction of reactive oxygen and nitrogen species, lowered antioxidant defense and alterations of enzymatic pathways in humans with poorly controlled diabetes mellitus can contribute to endothelial, vascular and neurovascular dysfunction (Jakus, 2000). Over the past decade, there has been substantial interest in oxidative stress and its potential role in diabetogenesis, development of diabetic complications, atherosclerosis and associated cardiovascular disease. Cardiovascular disease is the leading cause of mortality in patients with diabetes. Myocardiac infarction and stroke constitute the cause of death in as many as $80 \%$ of subjects with type 2 diabetes (Giugliano \& Ceriello, 1996).

Several studies in human and animal models have shown alterations in the antioxidant status in diabetes. Especially, disturbances in the defense system in various tissues from animals with experimental diabetes are reported. So far, a number of experiments have been performed to evaluate changes in the antioxidative system of the diabetic heart (Kakkar et al., 1996; Yadav et al., 1997a; 1997b; Tatsuki et al., 1997; Kowluru et al., 2000; Mak et al., 1996; Matkovics et al., 1997/1998; Stefek et al., 2000; Parinandi et al., 1990; Sun et al., 1999; Doi et al., 2001).

The activity of superoxide dismutase (SOD) increased in diabetic myocardium during 7, 6 and 32 weeks of the disease (Kakkar et al., 1996; Yadav et al., 1997a; Stefek et al., 2000). Matkovics et al. (1997/1998) reported that the SOD activity in the heart was midly elevated $48 \mathrm{~h}$ after alloxan treatment.
The activity of catalase (CAT) was markedly elevated in diabetic myocardium during 32 weeks (Stefek et al., 2000) and after $48 \mathrm{~h}$ of diabetes (Matkovics et al., 1997/1998). Similar results were obtained by Tatsuki et al. (1997) and by Kakkar et al. (1996). On the other hand, Yadaw et al. (1997b) reported that CAT activity in the diabetic heart was not affected.

Total glutathione (GSH) level was slightly increased in the heart tissue at the 15 th week of diabetes (Mak et al., 1996). Kakkar et al. (1996) stated that glutathione peroxidase (GSH-Px) activity in the heart increased significantly during 6 weeks of the experiment. Parinandi et al. (1990) reported an increase in the level of GSH and GSH-Px activity. On the other hand, Yadaw et al. (1997b) reported that GSH content and glutathione reductase (GSSG-R) activity in the heart tissue were markedly lowered. In the study of Doi et al. (2001) the GSH level was also significantly reduced.

Sun et al. (1999) stated that ascorbic acid concentration of diabetic hearts decreased significantly after 8 weeks of the experiment.

Parinandi et al. (1990) did not observe an intensification of lipid peroxidation (LPO) in the diabetic heart. In other experiment the level of LPO products significantly increased 2 weeks after the initiation of diabetes, after 7 weeks it returned to the level of the control (Tatsuki et al., 1997). An increase of lipid peroxidation was also observed in the cardiac muscle tissue during 32 weeks of diabetes (Stefek et al., 2000), after 8 weeks (Sun et al., 1999; Kowluru et al., 2000), at various stages of disease (0 to 6 weeks) (Kakkar et al., 1996) and $48 \mathrm{~h}$ after alloxan treatment (Matkovics $e t$ al., 1997/1998).

We decided to examine the long-term effect of the diabetogenic alloxan by determining the parameters of the antioxidative status in diabetic heart at various stages of development of the disease (3, 6, 12 and 24 weeks). We examined the enzymatic antioxidants SOD, CAT, GSH-Px, GSSG-R and non-enzy- 
matic parameters - vitamin $\mathrm{C}$ and $\mathrm{SH}$ group containing compounds. Lipid peroxidation was also monitored at each stage of the experiment.

\section{MATERIALS AND METHODS}

Alloxan, $\mathrm{KH}_{2} \mathrm{PO}_{4}, \mathrm{Na}_{2}$ EDTA, butylated hydroxytoluene (BHT), crystalline bovine serum albumin, Folin-Ciocalteu phenol reagent, L-ascorbic acid standard, 5,5-dithiobis-(2-nitrobenzoic acid) were from Sigma Chemicals Co. (U.S.A.). The Bioxytech SOD-525, Bioxytech GPx-340, Bioxytech GR-340 and Bioxytech LPO-586 kits were from Oxis International S.A. (U.S.A.). Glucose concentration was measured in serum with the Cormay GS-120L diagnostic kit (PZ Cormay, Poland).

The institutions guide lines for the care and use of laboratory animals was observed. The animals used were male New Zealand rabbits of the mean body mass of $2880 \mathrm{~g}$. The rabbits were fed standard diet and were given water ad libitum. Diabetes was induced by a single intravenous (i.v.) injection of alloxan $(100 \mathrm{mg} / \mathrm{kg})$ in physiological saline solution. The control animals were injected with physiological saline alone. Seven days after alloxan administration serum glucose concentration was measured. All alloxan-treated animals in which glucose concentration in the serum was lower than $11 \mathrm{mmol} / \mathrm{l}$ were excluded from the experiment. Glucose concentration and body mass were monitored weekly and at the time of sacrifice (after 3, 6, 12 and 24 weeks of disease). The animals were anaesthetized with pentobarbital sodium (60 $\mathrm{mg} / \mathrm{kg}$, i.v.), the heart of each animal was removed, washed with ice-cold physiological saline solution, dried and processed for biochemical measurements.

Homogenates were prepared on ice in the ratio $4 \mathrm{~g}$ tissue for $16 \mathrm{ml}$ of phosphate buffer, $\mathrm{pH} 7.5$, containing $1 \mathrm{mmol} / \mathrm{Na}_{2}$ EDTA. For each sample $10 \mu \mathrm{l}$ of $500 \mathrm{mmol} / \mathrm{l} \mathrm{BHT}$ in acetonitrile was added to prevent formation of new peroxides during the assay. The homogenates were centrifuged at $20000 \times \mathbf{g}$ for 15 min at $4^{\circ} \mathrm{C}$ and frozen at $-70^{\circ} \mathrm{C}$ until analysis.

Protein was determined in diluted aliquots of the homogenates by the method of Lowry (Lowry et al., 1951). The method used for the assay of $\mathrm{Cu}, \mathrm{Zn}-\mathrm{SOD}$ (EC 1.15.1.1) activity was based on the SOD-mediated increase in the rate of autooxidation of 5,6,6a,11b-tetrahydro-3,9,10-trihydroxybenzo(c)fluorene at pH 8.8 to yield a chromophore with maximum absorption at $525 \mathrm{~nm}$. Cu,Zn-SOD activity was determined after extraction from the homogenates with absolute ethanol-chloroform. CAT (EC 1.11.1.9) activity was assayed by the decrease in absorbance of hydrogen peroxide at $240 \mathrm{~nm}$ as described by Aebi (1984). GSH-Px (EC 1.11.1.6) activity was measured spectrophotometrically at $340 \mathrm{~nm}$, GSH formation being monitored by measurement of oxidation of NADPH to NADP. The GSSG-R (EC 1.6.4.2) assay was based on the reduction of oxidized glutathione (GSSG) determined indirectly by the measurement of the consumption of NADPH, as demonstrated by a decrease in absorbance at 340 $\mathrm{nm}$. Total SH group containing compounds were estimated according to Ellman (1959), using 5,5-dithio-bis-(nitrobenzoic acid) and measuring spectrophotometrically at 412 $\mathrm{nm}$. Ascorbic acid concentration was assayed according to Kyaw (1978), using a simple acid phosphotungstate procedure. LPO products were determined using the method based on the reaction with $N$-methyl-2-phenylindole to yield a stable chromophore with maximal absorption at $586 \mathrm{~nm}$. The method was used to assay malondialdehyde together with 4-hydroxyalkenals (MDA + 4-HNE).

The reported data are the means of measurements and their S.E.M. values. For statistical evaluation the Student's $t$-test and Statgraphics software were used. 


\section{RESULTS}

The initial mean value for serum glucose concentration was $6.39 \mathrm{mmol} / \mathrm{l}$. The level remained unchanged in the control groups but it increased progressively in the diabetic animals. At the 3rd week the mean glucose concentration was $22.0 \mathrm{mmol} / \mathrm{l}$, at the 6 th and 12th weeks 32.3 and $30.1 \mathrm{mmol} / \mathrm{l}$, respectively. At the 24 th week of the experiment the mean value for glucose concentration was $23.3 \mathrm{mmol} / \mathrm{l}$.

There was a progressive and significant increase in body mass of control rabbits. The diabetic animals showed a reduction in body mass, which attained at the $3 \mathrm{rd}$ week $6.6 \%$, at the 6 th week $2.5 \%$, at the 12 th and 24 th weeks $1.5 \%$ and $8.5 \%$, respectively. All other results are summarized in Table 1.

Within the diabetic groups $\mathrm{Cu}, \mathrm{Zn}-\mathrm{SOD}$ activity was significantly increased at all time intervals as compared to respective control, the most significantly at the $3 \mathrm{rd}$, 6th and 12 th weeks of the experiment.

There was a significant increase in CAT activity at the 3rd, 6th and 24 th weeks of disease. At the 12th week of experiment the activity of the enzyme was reduced below the level of the control group.

A significant increase of sulfhydryl compounds level was found at all time intervals. At the same time GSH-Px activity was significantly increased. GSSG-R activity in the diabetic heart increased at the $3 \mathrm{rd}$ week, decreased at the 6 th and 12 th weeks, then again increased above the level of the respective control group.

At the 3rd and 6th weeks of experiment we observed a significant decrease in the level of ascorbic acid. At the 12th and 24th weeks the concentrations of ascorbic acid were significantly higher than in the respective control groups.

Table 1. Antioxidant parameters and LPO products in the heart tissue of control (C) and diabetic (D) rabbits.

Values are the mean \pm S.E.M.; in the control groups $\mathrm{n}=4$.

\begin{tabular}{|c|c|c|c|c|c|c|c|c|c|c|c|c|c|c|}
\hline \multirow[t]{2}{*}{$\begin{array}{l}\text { Dura- } \\
\text { tion of } \\
\text { diabetes } \\
\text { (weeks) }\end{array}$} & \multicolumn{2}{|c|}{$\begin{array}{l}\text { SOD (U/mg } \\
\text { protein) }\end{array}$} & \multicolumn{2}{|c|}{$\begin{array}{l}\text { CAT } \\
\left(\mu \mathrm{mol} \mathrm{H}_{2} \mathrm{O}_{2} /\right. \\
\text { min per } \mathrm{mg} \\
\text { protein })\end{array}$} & \multicolumn{2}{|c|}{$\begin{array}{l}\mathrm{AA} \\
\text { (nmol/g } \\
\text { tissue) }\end{array}$} & \multicolumn{2}{|c|}{$\begin{array}{l}\text { LPO products } \\
\text { (nmol/g tissue) }\end{array}$} & \multicolumn{2}{|c|}{$\begin{array}{l}\text { GSH-Px } \\
\text { (mU/mg } \\
\text { protein) }\end{array}$} & \multicolumn{2}{|c|}{$\begin{array}{l}\text { GSSG-R } \\
\text { (mU/mg } \\
\text { protein) }\end{array}$} & \multicolumn{2}{|c|}{$\begin{array}{l}\mathrm{SH} \\
\text { (nmol/g tissue) }\end{array}$} \\
\hline & $\mathbf{C}$ & D & $\mathbf{C}$ & D & C & D & $\mathbf{C}$ & D & $\mathbf{C}$ & D & $\mathbf{C}$ & $\mathbf{D}$ & $\mathbf{C}$ & D \\
\hline 3 & $\begin{array}{l}1.8 \pm \\
0.2\end{array}$ & $\begin{array}{l}5.0 \pm \\
0.2 \\
\mathrm{n}=5^{\mathrm{a}}\end{array}$ & $\begin{array}{l}85.9 \pm \\
2.0\end{array}$ & $\begin{array}{l}104.8 \pm \\
0.9 \\
n=7^{\mathrm{a}}\end{array}$ & $\begin{array}{l}240 \pm \\
7\end{array}$ & $\begin{array}{l}221 \pm \\
2 \\
n=8\end{array}$ & $\begin{array}{l}36.8 \pm \\
0.3\end{array}$ & $\begin{array}{l}24.3 \pm \\
0.8 \\
n=4^{a}\end{array}$ & $\begin{array}{l}30.7 \pm \\
0.4\end{array}$ & $\begin{array}{l}42.5 \pm \\
0.8 \\
n=7^{\mathrm{a}}\end{array}$ & $\begin{array}{l}14.1 \pm \\
0.2\end{array}$ & $\begin{array}{l}14.6 \pm \\
0.1 \\
n=8\end{array}$ & $\begin{array}{l}1.46 \pm \\
0.05\end{array}$ & $\begin{array}{l}2.59 \pm \\
0.08 \\
n=8^{a}\end{array}$ \\
\hline 6 & $\begin{array}{l}1.8 \pm \\
0.2\end{array}$ & $\begin{array}{l}6.9 \pm \\
0.4 \\
\mathrm{n}=5^{\mathrm{a}}\end{array}$ & $\begin{array}{l}86.4 \pm \\
1.5\end{array}$ & $\begin{array}{l}108.9 \pm \\
1.5 \\
n=5^{\mathrm{a}}\end{array}$ & $\begin{array}{l}239 \pm \\
6\end{array}$ & $\begin{array}{l}207 \pm \\
2 \\
n=6^{a}\end{array}$ & $\begin{array}{l}36.9 \pm \\
0.3\end{array}$ & $\begin{array}{l}15.3 \pm \\
1.9 \\
n=4^{a}\end{array}$ & $\begin{array}{l}30.6 \pm \\
0.4\end{array}$ & $\begin{array}{l}69.0 \pm \\
0.5 \\
n=5^{a}\end{array}$ & $\begin{array}{l}14.1 \pm \\
0.2\end{array}$ & $\begin{array}{l}12.8 \pm \\
0.3 \\
n=4\end{array}$ & $\begin{array}{l}1.45 \pm \\
0.03\end{array}$ & $\begin{array}{l}2.63 \pm \\
0.04 \\
n=8^{a}\end{array}$ \\
\hline 12 & $\begin{array}{l}1.8 \pm \\
0.2\end{array}$ & $\begin{array}{l}5.1 \pm \\
0.2 \\
\mathrm{n}=5^{\mathrm{a}}\end{array}$ & $\begin{array}{l}88.0 \pm \\
1.9\end{array}$ & $\begin{array}{l}61.3 \pm \\
1.1 \\
\mathrm{n}=6^{\mathrm{a}}\end{array}$ & $\begin{array}{l}239 \pm \\
5\end{array}$ & $\begin{array}{l}298 \pm \\
4 \\
n=6\end{array}$ & $\begin{array}{l}36.8 \pm \\
0.3\end{array}$ & $\begin{array}{l}17.4 \pm \\
0.4 \\
\mathrm{n}=4^{\mathrm{a}}\end{array}$ & $\begin{array}{l}30.4 \pm \\
0.4\end{array}$ & $\begin{array}{l}54.9 \pm \\
0.8 \\
n=4^{a}\end{array}$ & $\begin{array}{l}14.2 \pm \\
0.1\end{array}$ & $\begin{array}{l}9.7 \pm \\
0.2 \\
\mathrm{n}=6^{\mathrm{a}}\end{array}$ & $\begin{array}{l}1.47 \pm \\
0.03\end{array}$ & $\begin{array}{l}2.89 \pm \\
0.05 \\
n=8^{a}\end{array}$ \\
\hline 24 & $\begin{array}{l}1.8 \pm \\
0.1\end{array}$ & $\begin{array}{l}3.1 \pm \\
0.2 \\
n=4\end{array}$ & $\begin{array}{l}89.1 \pm \\
1.1\end{array}$ & $\begin{array}{l}102.9 \pm \\
1.7 \\
\mathrm{n}=5^{\mathrm{a}}\end{array}$ & $\begin{array}{l}239 \pm \\
6\end{array}$ & $\begin{array}{l}267 \pm \\
5 \\
n=4^{d}\end{array}$ & $\begin{array}{l}37.1 \pm \\
0.3\end{array}$ & $\begin{array}{l}61.4 \pm \\
0.9 \\
n=4^{\mathrm{a}}\end{array}$ & $\begin{array}{l}30.3 \pm \\
0.4\end{array}$ & $\begin{array}{l}61.0 \pm \\
1.5 \\
\mathrm{n}=4^{\mathrm{a}}\end{array}$ & $\begin{array}{l}14.2 \pm \\
0.1\end{array}$ & $\begin{array}{l}14.8 \pm \\
0.2 \\
n=4\end{array}$ & $\begin{array}{l}1.47 \pm \\
0.04\end{array}$ & $\begin{array}{l}2.72 \pm \\
0.07 \\
\mathrm{n}=5^{\mathrm{a}}\end{array}$ \\
\hline
\end{tabular}

\footnotetext{
${ }^{\mathrm{a}}$ Significantly different from control at $P<0.001$; ${ }^{\mathrm{b}}$ significantly different from control at $P<0.005$; 'significantly different
} from control at $P<0.01$; ${ }^{\mathrm{d}}$ significantly different from control at $P<0.05$; ${ }^{\mathrm{e}}$ not significantly different from control 
We found a decrease in the level of LPO products (estimated as MDA + 4-HNE) at the $3 \mathrm{rd}, 6$ th and 12 th weeks of diabetes. After 24 weeks of the disease the level of LPO products was significantly higher in diabetic animals than in the control group.

\section{DISCUSSION}

In our investigations $\mathrm{Cu}, \mathrm{Zn}-\mathrm{SOD}$ activity increased in the heart of diabetic animals probably to increase dismutation of superoxide anions as a compensatory activation mechanism. Similar results were obtained in other experiments (Kakkar et al., 1996; Yadav et al., 1997a; Matkovics et al., 1997/1998; Stefek et al., 2000).

The increase of CAT activity at the 3rd, 6th and 24th weeks of our experiment and in other tests (Kakkar et al., 1996; Tatsuki et al., 1997; Matkovics et al., 1997/1998; Stefek et al., 2000) suggests a compensatory response to oxidative stress due to an increase in endogenous $\mathrm{H}_{2} \mathrm{O}_{2}$ production.

A significant increase in the level of sulfhydryl compounds and GSH-Px activity and a less significant one in the GSSG-R activity during the experiment confirms an efficacious defense of the diabetic heart against oxidative stress. The data obtained were similar to those presented by other authors (Kakkar et al., 1996; Mak et al., 1996; Parinandi et al., 1990).

Ascorbic acid is a major antioxidant that is essential for the scavenging of toxic free radicals in both blood and tissues. The disturbances in ascorbic acid metabolism in diabetes are therefore of great interest and might be important in the pathogenesis of some diabetic complications (Opoka-Winiarska, 2001). The active transport of ascorbic acid appears to be decreased by hyperglycaemia and insulin deficiency. Hyperglycaemia has also been shown to inhibit the uptake of dehydroascorbic acid, the oxidized species of vitamin $\mathrm{C}$ (Akkus et al., 1996).
In the diabetic heart we observed a decrease in the level of ascorbic acid after 6 weeks and then an increase up to the 24 th week of the experiment. In a previous paper, the lowered level of ascorbic acid was found in the heart after 8 weeks of the experiment (Sun et al., 1999).

Because of an impaired balance between the generation of free radicals and antioxidant defense systems some lipid peroxidation products or degradation products may be formed (Inouye et al., 1999). Since polyunsaturated fatty acid peroxides generate malondialdehyde and 4-hydroxyalkenals, measurement of MDA and 4-HNE may be used as an indicator of lipid peroxidation.

In the present work we used a method based on the reaction of MDA and 4-HNE with a chromogenic reagent to form a stable product with maximal absorption at $586 \mathrm{~nm}$. The applied method is more specific than the most frequently used thiobarbituric acid (TBA) test because several other compounds give colour products having absorption at the maximum of the TBA-MDA complex (Inouye, 1998).

In our experiment, the heart lipid peroxidation did not increase during 12 weeks of the disease, probably due to the elevated activities of SOD and GSH-Px and to the high level of sulfhydryl compounds. Similar results were reported by Parinandi et al. (1990) and Tatsuki et al. (1997). Data to the countrary were obtained by other authors (Kakkar et al., 1996; Sun et al., 1999; Kowluru et al., 2000; Stefek et al., 2000).

In summary, we report significant differences between the diabetic and control groups. However, the defense mechanisms in the heart were fairly efficacious against oxidative stress under diabetic conditions. This was demonstrated by the high levels of antioxidative compounds and the relatively low concentration of LPO products, especially during the first 12 weeks of diabetes. The tissue levels of the compounds mentioned seemed to depend on the stage of diabetes. 


\section{R E F E R E N C E S}

Aebi H. (1984) Catalase in vitro. Methods Enzymol.; 105: 121-6.

Akkus I, Kalak S, Vural H, Caglayan O, Menekse E, Can G, Durmus B. (1996) Leukocyte lipid peroxidation, superoxide dismutase, glutathione peroxidase and serum and leukocyte vitamin $\mathrm{C}$ levels of patients with type II diabetes mellitus. Clin Chim Acta.; 244: 221-7.

Bonnefont-Rousselot D, Bastard JP, Delattre J. (2000) Consequences of the diabetic status on the oxidant/antioxidant balance. Diabetes Metab.; 26: 163-76.

Doi K, Sawada F, Toda G, Yamachika S, Seto S, Urata Y, Sakata N, Tanigchi N, Kondo T, Yano K. (2001) Alteration of antioxidants during the progression of heart disease in streptozotocin-induced diabetic rats. Free Radic Res.; 34: 251-61.

Ellman GL. (1959) Tissue sulfhydryl groups. Arch Biochem Biophys.; 82: 70-7.

Giugliano D, Ceriello A. (1996) Oxidative stress and diabetic vascular complications. Diabetes Care.; 19: 257-67.

Inouye M, Hashimoto H, Mio T, Sumino K. (1998) Levels of lipid peroxidation product and glycated hemoglobin $\mathrm{A}_{1} \mathrm{c}$ in the erythrocytes of diabetic patients. Clin Chim Acta.; 276: 163-72.

Inouye M, Mio T, Sumino K. (1999) Link between glycation and lipooxidation in red blood cells in diabetes. Clin Chim Acta.; 285: 35-44.

Jakus V. (2000) The role of free radicals, oxidative stress and antioxidant systems in diabetic vascular disease. Bratisl Lek Listy.; 101: 541-51.

Kakkar R, Mantha SV, Kalra J, Prasad K. (1996) Time course study of oxidative stress in aorta and heart of diabetic rat. Clin Sci.; 91: $441-8$.

Kowluru RA., Engerman RL, Kern, TS. (2000) Diabetes-induced metabolic abnormalities in myocardium: effect of antioxidant therapy. Free Radical Res.; 32: 67-74.

Kyaw A. (1978) A simple colorimetric method for ascorbic acid determination in blood plasma. Clin Chim Acta.; 86: 153-67.

Lowry OH, Rosebrough NJ, Farr AL., Randall RJ. (1951) Protein measurement with Folin phenol reagent. J Biol Chem.; 193: 265-7.

Mak DH, Ip SP, Poon MK, Ko KM. (1996) Alterations in tissue glutathione antioxidant system in streptozotocin-induced diabetic rats. Mol Cell Biochem.; 162: 153-8.

Matkovics B, Sasvari M, Kotorman M, Varga IS, Hai DQ, Varga C. (1997/1998) Further prove on oxidative stress in alloxan diabetic rat tissues. Acta Physiol Hung.; 85: 183-92.

Opoka-Winiarska V. (2001) Impaired metabolism and effects of vitamin $\mathrm{C}$ supplementation on diabetes. Diabetol Pol.; 7: 208-11.

Parinandi NL, Thompson EW, Schmid HHO. (1990) Diabetic heart and kidney exhibit increased resistance to lipid peroxidation.

Biochim Biophys Acta.; 1047: 63-9.

Stefek M, Sotnikova R, Okruhlicova L, Volkovova K, Kucharska J, Gajdosik A, Gajdosikova A, Michalova D, Hozova R, Tribulova N, Gvozdjakova A. (2000) Effect of dietary supplementation with the pyridoindole antioxidant stobadine on antioxidant state and ultrastructure of diabetic rat myocardium. Acta Diabetol.; 37: 111-7.

Sun F, Iwaguchi K, Shudo R, Nagaki Y, Tanaka K, Ikeda K, Tokumaru S, Kojo S. (1999) Change in tissue concentrations of lipid hydroperoxides, vitamin $\mathrm{C}$ and vitamin $\mathrm{E}$ in rats with streptozotocin-induced diabetes. Clin Sci.; 96: 185-90.

Tatsuki R, Satoh K, Yamamoto A, Hoshi K, Ichihara K. (1997) Lipid peroxidation in the pancreas and other organs in streptozotocin diabetic rats. Jpn J Pharmacol.; 75: 267-73.

Yadav P, Sarkar S, Bhatnagar D. (1997a) Lipid peroxidation and antioxidant enzymes in 
erythrocytes and tissues in aged diabetic rats. Indian $J$ Exp Biol; 35: 389-92.

Yadav P, Sarkar S, Bhatnagar D. (1997b) Action of Capparis decidua against alloxan-induced oxidative stress and diabetes in rat tissues. Pharmacol Res;. 36: 221-8.

West IC. (2000) Radicals and oxidative stress in diabetes. Diabet Med.; 17: 171-80. 